\title{
Conformational changes in the hepatitis A virus capsid in response to acidic conditions
}

\author{
N. E. BISHOP \\ Hepatitis Research Unit, Macfarlane Burnet Centre for Medical Research, PO Box 254, Fairfield, Victoria, \\ Australia 3078
}

\begin{abstract}
Low pH values encountered during uptake of viruses by receptor-mediated endocytosis have been shown to expose hydrophobic residues of many viruses and result in viral conformational changes leading to uncoating of the viral genome. An assay for hydrophobicity utilising the non-ionic detergent Triton X-114 was established, making use of metabolically-labelled hepatitis A virus (HAV). In this assay, hydrophilic proteins interact with the aqueous (buffer) phase, while hydrophobic proteins interact with the Triton (detergent) phase. HAV particles interact with the aqueous phase at neutral pH, whereas, under acidic conditions, HAV was found predominantly in the detergent phase. This indicates that the capsid of HAV undergoes conformational changes rendering the particle more hydrophobic under acidic conditions. A further two conformational changes were found in $\mathrm{HAV}$ on exposure to low $\mathrm{pH}$, as detected by changes in buoyant density in $\mathrm{CsCl}$ gradients. These were maturation of provirions to virions and the formation of dense particles. These results may have implications for uncoating of the HAV RNA genome, and these conformational changes could represent intermediates in the viral uncoating process.
\end{abstract}

\section{Introduction}

Hepatitis A virus (HAV) is the sole member of the hepatovirus genus within the picornavirus family $[1,2]$. Picornaviruses enter the host cell by the use of specific receptors, and the presence of a saturable HAV receptor on several cell lines has recently been demonstrated [3]. Early studies suggested that HAV entry into cells requires a cell-surface complex involving phospholipids, proteins and galactose [4], and recently two surface glycoproteins have been identified on African green monkey kidney cells as receptors for HAV $[5,6]$. Attachment of HAV to susceptible cells is strongly dependent on the presence of calcium ions or acidic conditions $[3,7,8]$. Both calcium ions and low $\mathrm{pH}$ have been shown to increase the strength of the HAVreceptor interaction, resulting in decreased elution of bound particles from the cell surface [8].

Received 11 Feb. 1998; accepted 24 Aug. 1998.

Corresponding author: Dr N. E. Bishop. Present address: Division of Biochemistry, School of Biological Sciences, University of Manchester, 2.205 Stopford Building, Oxford Road, Manchester M13 9PT.
After receptor binding, many viruses are thought to enter cells via coated pit regions on the cell surface. The mechanism of entry via coated pits and subsequent endocytosis seems to rely on the acidic $\mathrm{pH}$ in the vesicles because of two observations: (i) studies with lysosomotropic agents or weak bases, which raise the $\mathrm{pH}$ of endosomes to near neutrality, inhibit entry of many viruses; and (ii) viruses and toxins thought to enter cells via acidic vesicles require low $\mathrm{pH}$ to interact with membranes, including poliovirus (PV), the prototype of the picornavirus family [9].

The mode of entry of PV is thought to involve the formation of altered particles (A-particles) which have lost capsid protein VP4 and have a more hydrophobic exterior [9-11]. These particles are non-infectious and can be found eluting from cells after the viral attachment step [12-15]. A-particles are presumably capable of interaction with the endosomal membrane, facilitating release of viral RNA into the cytoplasm, by virtue of their hydrophobic nature.

Preliminary experimental evidence available on the entry of HAV into susceptible cells suggests that HAV entry into cells occurs via receptor-mediated endocytosis, as HAV infection can be prevented by treatment of 
cells with monensin, ammonium chloride, amantadine, dansylcadaverine and methylamine, agents that prevent endosomal acidification $[16,17]$. In direct contrast with PV infection, the majority of HAV particles eluted from cells remain infectious and particles with altered sedimentation coefficients do not appear to be formed during receptor binding [8]. However, as the HAV VP4 molecule is thought to be extremely small [18] compared with that of most picornaviruses, its loss from virions would not necessarily be expected to lead to a detectable change in sedimentation coefficient. Therefore, it remained possible that hepatitis A virions do undergo conformational changes when exposed to the acidic conditions, but these cannot be detected by sedimentation on sucrose density gradients.

Alteration of HAV leading to uncoating of viral RNA is presumed to occur either within the environment of endosomes originating from clathrin-coated vesicles $[16,17]$, which are known to become acidic over time [19], or within vesicles derived from non-clathrincoated regions of the cell surface, which can also become acidified [20]. Although HAV has been reported to be extremely stable under conditions of $\mathrm{pH} 1-11$ at $20^{\circ} \mathrm{C}[21,22]$ the effect of moderately low $\mathrm{pH}$ values such as those found within the endosomal pathway ( $\mathrm{pH} 6.0-4.8$ ), at $37^{\circ} \mathrm{C}$ on $\mathrm{HAV}$ particles, has never been examined. HAV particles may undergo subtle conformational changes on exposure to these conditions. Part of these conformational changes may cause HAV particles to become more hydrophobic, facilitate interaction with the endosomal membrane, and thus mediate viral uncoating.

This study set out to determine, by examining changes in hydrophobicity and buoyant density, whether HAV undergoes conformational changes in response to acidic conditions, such as those found within the endosomal pathways of cells $[19,20]$.

\section{Materials and methods}

\section{Virus and cells}

The strain of HAV used in these experiments is known as HM175A.2 and is a cytopathic variant which grows relatively rapidly in cell culture [23,24]. Virus was propagated in BS-C-1 cells and purified by discontinuous glycerol/sucrose gradient ultracentrifugation as described by Bishop and co-workers [25].

\section{Production of radiolabelled $H A V$}

$\mathrm{HAV}$ was metabolically labelled with ${ }^{35} \mathrm{~S}$-methionine and ${ }^{35}$ S-cysteine, as described elsewhere [26]. BS-C-1 cells were infected with $\mathrm{HAV}$ and incubated in culture medium for $12 \mathrm{~h}$ at $37^{\circ} \mathrm{C}$. The medium was then removed and replaced with methionine- and cysteinefree medium and incubated for a further $3 \mathrm{~h}$ at $37^{\circ} \mathrm{C}$, before the addition of medium containing $(/ \mathrm{ml}) c$.
$150 \mu \mathrm{Ci}$ of $\mathrm{L}^{35} \mathrm{~S}-\mathrm{methionine}$ and $30 \mu \mathrm{Ci}$ of $\mathrm{L}-{ }^{35} \mathrm{~S}-$ cysteine for incubation for a further $3 \mathrm{~h}$ at $37^{\circ} \mathrm{C}$. After this time, label was removed and replaced with normal culture medium until the cells were harvested at 24$36 \mathrm{~h}$ after infection. Labelled virus particles were purified by linear sucrose density gradient ultracentrifugation.

\section{Linear sucrose gradient ultracentrifugation}

Radiolabelled HAV particles were purified by sucrose gradient ultracentrifugation [27]. Briefly, sucrose gradients of $10-30 \% \mathrm{w} / \mathrm{v}$ were prepared in Beckman SW41 tubes and allowed to equilibrate. Samples of cell lysate were layered on top and centrifuged for $2.5 \mathrm{~h}$ at $150000 \mathrm{~g}$ at $4^{\circ} \mathrm{C}$. Fractions were collected from the bottom of the tube and the first three or four fractions of $1 \mathrm{ml}$ were pooled.

\section{Hydrophobicity assay}

A stock solution of Triton X-114 (Sigma) 4\% w/v was prepared by dissolving $40 \mathrm{~g}$ of detergent in $1000 \mathrm{ml}$ of $20 \mathrm{~m} \mathrm{M}$ sodium phosphate buffer ( $\mathrm{pH} 7.5$ ) containing $140 \mathrm{mM} \mathrm{NaCl}$, by stirring overnight at $4^{\circ} \mathrm{C}$. The resulting solution was then incubated at $37^{\circ} \mathrm{C}$ until two phases appeared, according to the method of Madshus and co-workers [9]. The upper phase, which consisted of buffer, was discarded and replaced by fresh buffer and this procedure was repeated three times. After the final condensation, the pre-treated Triton X-114 was made up to $200 \mathrm{ml}$ in the same buffer.

Radiolabelled HAV was mixed with buffered saline of various $\mathrm{pH}$ values in siliconised microfuge tubes, before the addition of Triton $\mathrm{X}-114$ at $4^{\circ} \mathrm{C}$, by the method described by Skern et al. [28]. This solution became homogeneous with gentle mixing at temperatures of $\leqslant 18^{\circ} \mathrm{C}$. Tubes were then placed at $37^{\circ} \mathrm{C}$ for $30 \mathrm{~min}$ to allow the phases to separate and centrifuged for $2 \mathrm{~min}$ at room temperature. The aqueous phase was removed and radioactivity in both phases was determined after precipitation with trichloroacetic acid.

\section{Trichloroacetic acid precipitation}

Samples of detergent or aqueous phase were spotted on to 25-mm disks of Whatman GF/A glass fibre paper and allowed to dry at $22^{\circ} \mathrm{C}$. Disks were places in a bath of ice-cold trichloroacetic acid (TCA) for $10 \mathrm{~min}$, washed three times in cold TCA $5 \%$, then washed once in cold absolute ethanol for $10 \mathrm{~min}$. The disks were airdried and covered with $3 \mathrm{ml}$ of Insta-gel liquid scintillation cocktail (Packard Instrument, USA). After incubation at $22^{\circ} \mathrm{C}$ for $2-4 \mathrm{~h}$, the amount of radioactivity was measured in a Packard liquid scintillation spectrophotometer. 


\section{Isopycnic CsCl gradient ultracentrifugation}

$\mathrm{CsCl}$ was diluted to a buoyant density of $1.33 \mathrm{~g} / \mathrm{cm}^{3}$. Gradients were pre-formed for $6 \mathrm{~h}$ at $18^{\circ} \mathrm{C}$ in a Beckman SW41 rotor at $150000 \mathrm{~g}$. A $1-\mathrm{ml}$ volume of lysate (of varying $\mathrm{pH}$ ) was layered on to the gradient and centrifuged for a further $18 \mathrm{~h}$ under the same conditions. Fractions of c. $0.6 \mathrm{ml}$ were collected from the bottom of the gradient. The buoyant density of fractions was determined from their refractive index.

\section{Detection of HAV RNA}

Viral positive-stranded RNA was detected in $\mathrm{CsCl}$ gradient fractions by dot-blot hybridisation, as described by Anderson and Ross [18]. Briefly, HAV fractions were mixed with FSSC $(6.1 \mathrm{M}$ formaldehyde,

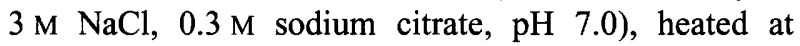
$65^{\circ} \mathrm{C}$ for $15 \mathrm{~min}$ and applied to nitrocellulose membranes. Filters were then probed with ${ }^{32} \mathrm{P}$-labelled negative-strand RNA probes, and exposed to preflashed film at $-70^{\circ} \mathrm{C}$. Densitometry was performed with the BioRad system and intensity values (adjusted for local background) were calculated as OD $\times \mathrm{mm}^{2}$. Values are relative and are comparable between gradients, but absolute values were not quantified. The accuracy in values of fractions 13 and 14 of the neutral $\mathrm{pH}$ gradient (Fig. 2b) was decreased due to the strong intensity of the signal which led to superimposition of the two signals (Fig. 2a). This analysis was kindly performed by $\mathrm{Dr}$ P. Gribbon at the University of Manchester.

\section{Results}

\section{Effect of low $\mathrm{pH}$ on the hydrophobicity of $H A V$}

As Triton $\mathrm{X}-114$ is a mild detergent, native protein structure should be maintained during detergent treatment [29]. Bordier [30] demonstrated that hydrophilic proteins partition to the aqueous (top) phase and hydrophobic proteins are found in the detergent (bottom) phase. To determine whether HAV particles may become more hydrophobic and thereby facilitate interaction with the endosomal membrane, the ability of ${ }^{35} \mathrm{~S}$-labelled HAV to enter the detergent phase at $\mathrm{pH}$ 4.8, pH 5.5, or pH 7.6 was examined (Table 1; Fig. 1a). At neutral $\mathrm{pH}$ most of the radioactivity remained in the aqueous phase $(92 \%)$, whereas at $\mathrm{pH}$ values of 5.5 or

Table 1. Hydrophobicity of radiolabelled HAV particles, determined by partitioning into Triton X-114

\begin{tabular}{|c|c|c|c|c|}
\hline \multirow[b]{2}{*}{$\mathrm{pH}$ value } & \multicolumn{2}{|c|}{ Average $\mathrm{cpm}$ in } & \multicolumn{2}{|c|}{ Percentage in phase } \\
\hline & $\begin{array}{l}\text { Aqueous } \\
\text { phase* }^{*}\end{array}$ & $\begin{array}{c}\text { Detergent } \\
\text { phase }^{*}\end{array}$ & Aqueous & Detergent \\
\hline 7.6 & $8274 \mathrm{SD} 5$ & $753 \mathrm{SD} 57$ & 92 & 8 \\
\hline 5.5 & $1203 \mathrm{SD} 22$ & 6817 SD 171 & 15 & 85 \\
\hline 4.8 & $778 \mathrm{SD} 45$ & $8036 \mathrm{SD} 231$ & 9 & 91 \\
\hline
\end{tabular}

*Values are presented as average cpm and SD of duplicate samples.
4.8 , increasing amounts of labelled virus were found in the Triton $\mathrm{X}-114$ phase $(85 \%$ and $91 \%$ respectively, compared with $8 \%$ at $\mathrm{pH} 7.6$ ). These data indicate that $\mathrm{HAV}$ exposes hydrophobic domains at acidic $\mathrm{pH}$.

This trend was confirmed in a further three experiments (Fig. 1b-d), where the effect of different $\mathrm{pH}$ ranges on the hydrophobicity of HAV particles were examined and compared with those of the initial experiment. In the first of these hydrophobicity assays (Fig. 1b) a fresh preparation of radiolabelled HAV was used, and this viral pool was exposed to $\mathrm{pH}$ values identical to those outlined in Table 1. Less virus was converted to the hydrophobic form at $\mathrm{pH} 5.5$ and 4.8 than in the initial experiment. Presumably these differences were due to the use of a different viral pool and experimental variation.

The next purified viral pool was exposed to $\mathrm{pH} 7.0$, 6.5 and 5.0 (Fig. 1c); c. $30 \%$ of the viral pool partitioned in the hydrophobic phase at $\mathrm{pH} 7.0$, increasing to $c$. $40 \%$ at $\mathrm{pH} 6.5$ and $65 \%$ at $\mathrm{pH} 5.0$. These data further confirmed the trend that exposure of $\mathrm{HAV}$ viral particles to low $\mathrm{pH}$ resulted in an increase in hydrophobicity. A final preparation of radiolabelled viral particles was exposed to $\mathrm{pH} 7.0$, 6.0 or 5.0 and partitioned in Triton X-114 before analysis (Fig. 1d); c. $30 \%$ of virus was found to be hydrophobic at $\mathrm{pH} 7.0$, increasing to $c$. $60 \%$ at $\mathrm{pH} 6.0$ and $65 \%$ at $\mathrm{pH} 5.0$. These data indicate that HAV particles become more hydrophobic at low $\mathrm{pH}$, presumably by the exposure of previously hidden hydrophobic domains.

Comparison of the numbers of hydrophobic particles at $\mathrm{pH} 7.6$ and $\mathrm{pH} 7.0$ (comparing the starting levels of hydrophobic virus in Figs. $1 \mathrm{a}$ and $\mathrm{b}$ with those of Figs. 1c and d) would further indicate some changes in hydrophobicity on lowering the $\mathrm{pH}$ from 7.6 to 7.0. This was confirmed when the hydrophobicity at $\mathrm{pH}$ 7.6 was directly compared with that at $\mathrm{pH}$ 7.0. Furthermore, the conversion of HAV to a hydrophobic particle occurred to a similar degree between $\mathrm{pH} 4.8$ and $\mathrm{pH} 6.0$ (Fig. 1a and d). In no instance was the transfer of $\mathrm{HAV}$ to the detergent phase complete, whether at $\mathrm{pH} 5.0$ or $\mathrm{pH} 4.8$, which are the most acidic $\mathrm{pH}$ values expected to be encountered in the endosomal pathway of cells $[19,31,32]$.

\section{Effect of low pH on HAV buoyant density}

To determine whether low $\mathrm{pH}$-induced conformational changes in the HAV capsid corresponded to conformational changes detectable by other means, isopycnic $\mathrm{CsCl}$ gradient ultracentrifugation was used to examine virus samples exposed to low $(\mathrm{pH} 4.8)$, neutral $(\mathrm{pH}$ 7.6), or high ( $\mathrm{pH} 10.5) \mathrm{pH}$ at $37^{\circ} \mathrm{C}$ for $1 \mathrm{~h}$ (Fig. 2); 19 fractions of $c .0 .6 \mathrm{ml}$ were collected from the bottom of centrifugation tubes. HAV RNA-containing particles in fractions were detected by dot-blot hybridisation 


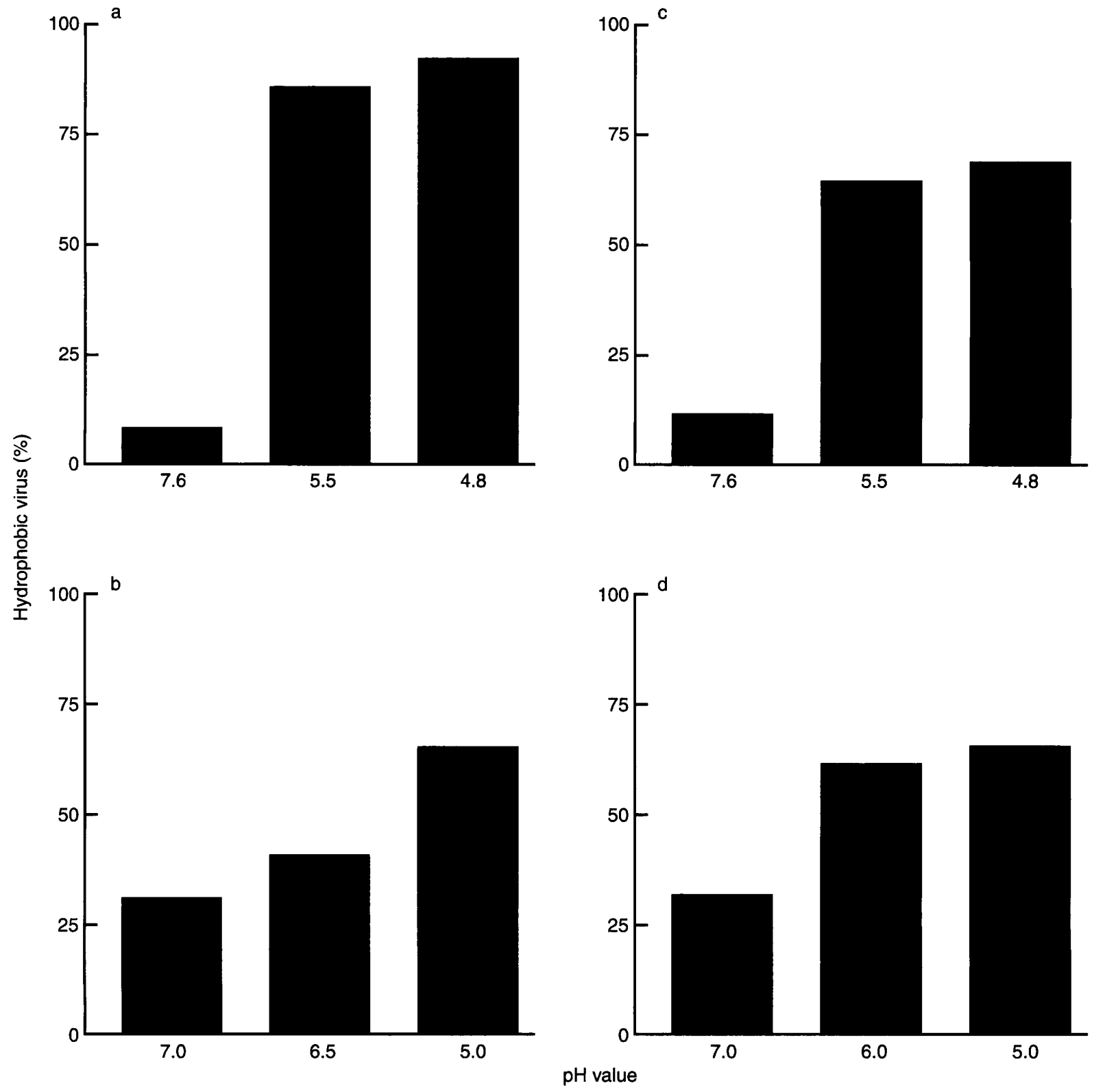

Fig. 1. Percentage hydrophobicity percentage of counts in the detergent phase of HAV labelled with ${ }^{35} \mathrm{~S}$-methionine and ${ }^{35}$ S-cysteine determined by partitioning into Triton $\mathrm{X}-114$ after exposure to various $\mathrm{pH}$ values. These results demonstrated an increase in hydrophobicity of HAV when the $\mathrm{pH}$ became acidic. (a), data from Table 1; (b-d), data obtained from three separate experiments.

(Fig. 2a). The relative signal intensity was quantified by densitometry (Fig. 2b).

HAV virions (containing predominantly VP2 and little VP0) were expected to band at c. $1.34 \mathrm{~g} / \mathrm{cm}^{3}$, whilst immature HAV provirions (containing predominantly VP0 and little VP2) were expected at c. $1.32 \mathrm{~g} / \mathrm{cm}^{3}$ $[27,33]$. At neutral pH HAV RNA-containing particles were found mainly in fractions $13-15$ (Fig. $2 \mathrm{a}$ and $\mathrm{b}$ ), corresponding to a buoyant density of $c .1 .32 \mathrm{~g} / \mathrm{cm}^{3}$ (Fig. 2c). This indicates that the viral preparation used contained a high proportion of immature HAV particles.

After exposure to acidic pH, HAV RNA-containing particles were predominantly found in fractions 2 and 3 , with lower levels of RNA spread over fractions 10-
15 , in contrast to the HAV particle profile at neutral $\mathrm{pH}$ (Fig. 2a and $\mathrm{b}$ ). The more dense particles in fractions 2 and 3 had a buoyant density of $>1.4 \mathrm{~g} / \mathrm{cm}^{3}$, whilst the particles in fractions $8-12$ had buoyant densities $c$. $1.34 \mathrm{~g} / \mathrm{cm}^{3}$ (Fig. 2c). This indicates that exposure to acidic conditions resulted in the conversion of immature provirions to virions and the formation of very dense $\left(>1.4 \mathrm{~g} / \mathrm{cm}^{3}\right) \mathrm{HAV}$ particles.

The HAV RNA-containing particle profile after exposure to alkaline conditions appeared intermediate to that observed on exposure of virus to acidic or neutral conditions (Fig. 2a and b). Whilst a small number of dense HAV RNA-containing particles were found in fractions 1 and 2, the majority were found in fractions 11-13 and had buoyant densities only slightly greater 
a

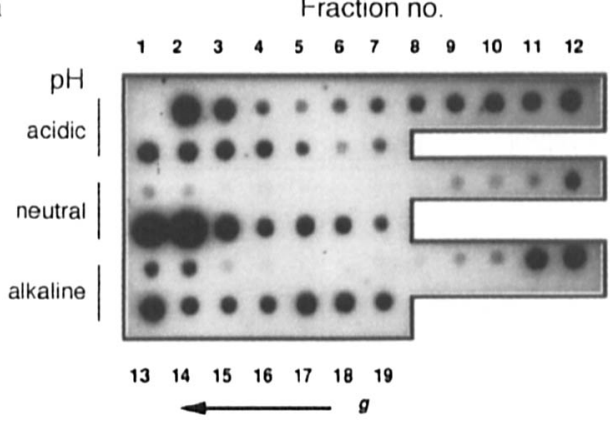

b

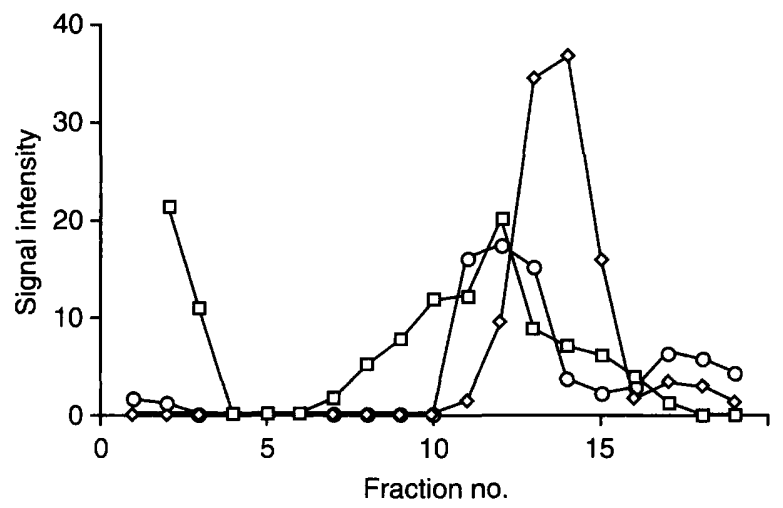

c

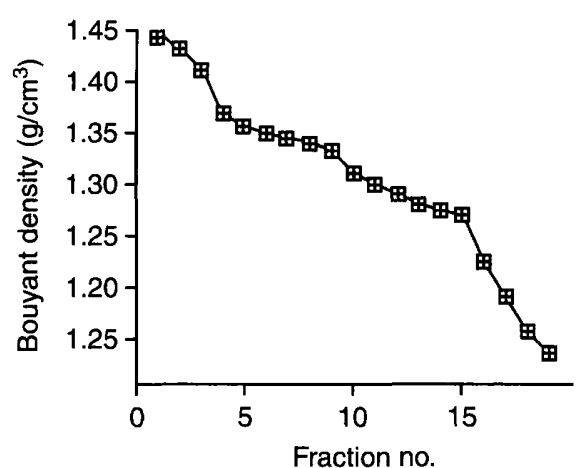

Fig. 2. Effect of $\mathrm{pH}$ values $4.8,7.6$ and 10.5 on the buoyant density profile of $\mathrm{HAV}$ particles in $\mathrm{CsCl}$ gradients. Fractions of $c .0 .6 \mathrm{ml}$ were examined for (a) positive-stranded HAV RNA by dot-blot hybridisation and with (b) signal intensity measurement ( $\square$ acidic, $\diamond$ neutral, $\bigcirc$ alkaline) and (c) buoyant density determination from the refractive indices. (Note that much of fraction 1 of the acidic gradient had been pooled with fraction 2.)

than those found in fractions $13-15$ at neutral $\mathrm{pH}$. This indicates that some conversion of immature provirions to more mature particles, intermediate in nature to virions, may have been occurring. In addition, some RNA was found in fractions 17 and 18, corresponding to less dense regions of the gradient. The identity of these latter particles is unknown, but they may represent particles that are partially disrupted under the conditions used.
Similar HAV density profiles were detected on exposure of virus to acidic conditions. Dense HAV particles and a conversion of immature provirions to mature virions was seen after $\mathrm{CsCl}$ density gradients of particles exposed to $\mathrm{pH}$ values in the range 3.05.5. The neutral $\mathrm{pH}$ particle profile remained similar between $\mathrm{pH}$ values 7.0 and 8.5 , thus differing somewhat from the data presented in Fig. 1, where conformational changes could be detected between $\mathrm{pH}$ 7.6 and 7.0. This difference could have a number of explanations and various hypotheses are being explored.

\section{Discussion}

HAV entering cells via the endosomal pathway would be exposed to conditions of acidic $\mathrm{pH}[16,17,20]$. Therefore low $\mathrm{pH}$ might be expected to increase the hydrophobicity of viral particles, thus mediating interaction with the endosomal membrane and release of the viral RNA into the cytoplasm. Such a mechanism has been proposed for uncoating of PV, the type member of the picornavirus family [9]. Hydrophobic particles of PV, known as A-particles, are non-infectious and have lost capsid protein VP4, resulting in particles with altered sedimentation coefficients [34]. Altered PV particles are detected eluting from cultured cells early in infection, contrasting with HAV infection, where eluting particles retain infectivity and do not have any detectable changes in sedimentation coefficient [8]. This paper documents for the first time changes in HAV on exposure to acidic conditions, including a gain in hydrophobicity, providing a rationale for the HAV uncoating process.

The data presented here indicate that exposure of HAV to low $\mathrm{pH}$ causes conformational changes in the capsid, resulting in more hydrophobic particles, as detected by a hydrophobic partition assay. In no instance was the transfer of HAV particles from the aqueous to the detergent phase complete, indicating that not all particles were capable of undergoing the hydrophobic transition. This was despite the use of $\mathrm{pH}$ values of 4.8 , representing the lowest $\mathrm{pH}$ values encountered in the endosomal/lysosomal pathway of cells $[19,31,32]$. Transfer of PV to the Triton X-114 detergent phase occurs half-maximally at $\mathrm{pH} 6.5$ [9], whilst similar studies on the partition of human rhinovirus type 14 in Triton X-114 showed approximately half-maximal partition into the detergent phase at close to $\mathrm{pH} 3$ [28]. However, the latter value is lower than that expected to be encountered during receptor-mediated endocytosis, and values this low were not examined.

HAV particles that do not undergo the hydrophobic transition and remain in the aqueous phase may be unable to uncoat. Alternatively, they may be empty viral capsids in the viral pool used for these studies. 
Empty capsids, lacking viral RNA, may not be able to undergo the same conformational changes as infectious HAV particles. A further possibility is that low $\mathrm{pH}$ on its own is not capable of reproducing conditions encountered by viruses during cell infection, and that more particles would undergo the hydrophobic transition if the cellular environment could be reproduced more faithfully. Further research utilising the assay described here can be used to examine this in more detail.

The hydrophobic changes induced in PV during cell entry are enhanced by receptor binding as well as acidic conditions [9]. The contribution of HAV receptor binding to changes in hydrophobicity likewise could be examined by modifying the methods employed in the present study. Interestingly, HAV receptor binding has been shown to be enhanced under acidic conditions, confirming that some form of conformational change can occur under these conditions to enhance virus-receptor interactions [8]. Whether this relates to the virus or receptor, and how this relates to subsequent virus uncoating remains unclear.

When HAV particles were treated to acidic conditions, two conformational changes could be detected by alterations in viral buoyant densities after centrifugation over isopycnic $\mathrm{CsCl}$ gradients. Exposure of virus particles (original density of $3.2 \mathrm{~g} / \mathrm{cm}^{3}$ at neutral $\mathrm{pH}$ ) to low $\mathrm{pH}$ led to the formation of two further forms of HAV particles. The first type of particles had densities only slightly greater than those found at neutral $\mathrm{pH}$ $\left(3.4 \mathrm{~g} / \mathrm{cm}^{3}\right.$ compared to $\left.3.2 \mathrm{~g} / \mathrm{cm}^{3}\right)$ and formed a continuous spectrum with the original particles in the gradient. The density of these particles is consistent with those of mature HAV virions [27,33], and is thought to occur via the autocatalytic cleavage of VP0 to VP2 which occurs under these conditions, converting immature provirions to mature virions [35]. Furthermore, there is direct preliminary evidence that acidic conditions lead to a more rapid autocatalytic cleavage of VP0 to VP2 than that occurring at neutral $\mathrm{pH}$ (Bishop and Anderson, unpublished observations). In the light of an increase in HAV hydrophobicity between $\mathrm{pH} 7.6$ and 7.0 (Fig. 1) not correlating with the detection of particles with high buoyant density, the hydrophobic properties of purified preparations of $\mathrm{HAV}$ provirions and virions will be compared.

The second type of particle formed under acidic conditions has a dramatically altered density of $c$. $1.4 \mathrm{~g} / \mathrm{cm}^{3}$ and was found at the bottom of $\mathrm{CsCl}$ gradients. Dense HAV particles have been detected previously in cell culture lysates $[36,37]$ and clinical samples [38-40], and are thought to result from a more open capsid configuration. Data on the infectivity of these three forms of $\mathrm{HAV}$ indicate that maturation of $\mathrm{HAV}$ provirions $\left(1.32 \mathrm{~g} / \mathrm{cm}^{3}\right)$ to virions $\left(1.34 \mathrm{~g} / \mathrm{cm}^{3}\right)$ results in an increase in infectivity

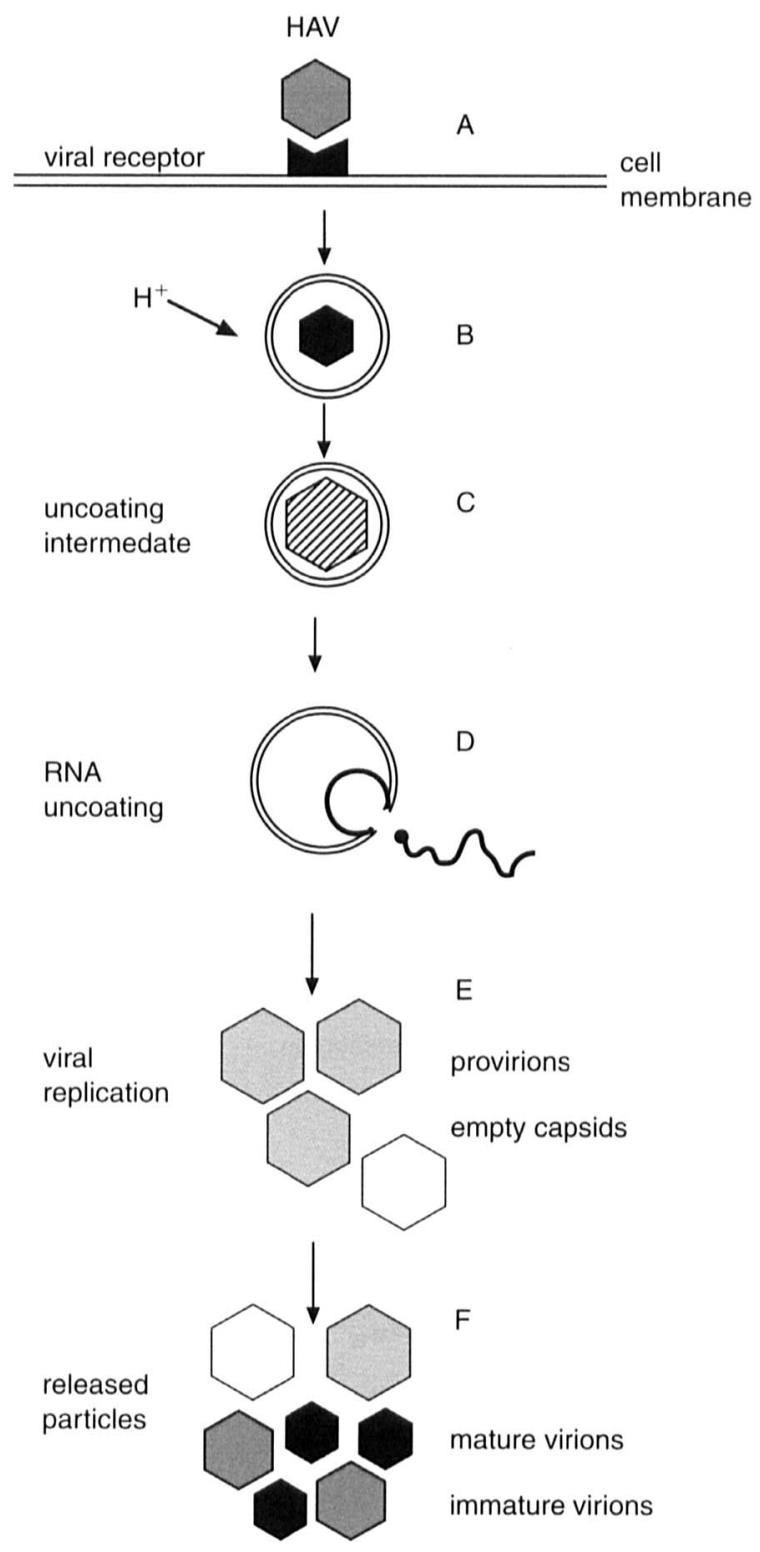

Fig. 3. Schematic representation of a working hypothesis of the entry and uncoating process of HAV in susceptible cells. Virions attach to cellular receptors (A) and are internalised by receptor-mediated endocytosis into endosomes (B). The endosomes are rapidly acidified due to the presence of an ATPase-dependent proton pump in the vesicle membrane. The first conformational change is caused by the autocatalytic cleavage of any VP0 molecules in viral capsids to VP2, creating mature virions. On exposure to low $\mathrm{pH}$, virions are then converted to a more hydrophobic form (C), detectable by partitioning into Triton X-114. These particles are formed by the exposure of formerly hidden hydrophobic residues of viral capsid proteins and renders particles permeable to $\mathrm{CsCl}$. This hydrophobic conformational change results in particles capable of being uncoated to release the viral RNA genome (D). Viral replication then ensues in the cytoplasm, leading to the production of intermediates in the viral morphogenic pathway $(\mathbf{E})$, i.e., provirions and procapsids. Maturation of provirions to virions (F) finally completes the viral replication cycle, but this process is generally not completed and a full spectrum of immature viral particles is released from cells [25]. 
$[27,35]$. However, dense HAV particles do not appear to be infectious (Bishop, unpublished observations).

Whilst the acidic conditions encountered during endocytosis may play a role in the entry of picornaviruses into cells, some more recent studies have questioned the role of vesicle acidification in the entry of PV into cells [41, 42]. Therefore, hypotheses involving the role of low ionic strength or divalent cations within endosomal vesicles have been put forward for PV uncoating [43]. The ability of these conditions to cause conformational changes in HAV can now be examined by modifications of the methods described here.

In conclusion, the results presented here identified three conformational changes in HAV in response to acidic conditions: (i) conversion of immature to mature virions, (ii) production of dense HAV particles and (iii) the generation of a more hydrophobic capsid structure. Preliminary evidence suggests that none of these changes is reversible (Bishop and Anderson, unpublished data). Clearly more work is needed to characterise these conformational alterations in more detail. A working model of how these changes might mediate viral uncoating is provided in Fig. 3 .

N.E.B. was supported by a Commonwealth Postgraduate Research Award and this work was assisted by the Macfarlane Burnet Centre Research Fund. I thank D. Anderson and S. Borovec for helpful discussions, S. Locarnini and J. Mills for critically reading this manuscript, and D. Colledge for technical assistance.

\section{References}

1. Francki RIB, Fauquet CM, Knudson DL, Brown F. Classification and nomenclature of viruses. In: Archives of virology, Suppl 2. Vienna, Springer. 1991.

2. Wimmer E, Murdin AD. Hepatitis A virus and the molecular biology of picornaviruses: a case for a new genus of the family Picornaviridae. In: Hollinger FB, Lemon SM, Margolis H (eds) Viral hepatitis and liver disease. Baltimore, Williams and Wilkins. 1991: 31-41

3. Stapleton JT, Frederick J, Meyer B. Hepatitis A virus attachment to cultured cell lines. J Infect Dis 1991; 164: $1098-1103$.

4. Seganti L, Superti F, Orsi N, Gabrieli R, Divizia M, Panà A Study of the chemical nature of $\operatorname{Frp} / 3$ cell recognition units for hepatitis A virus. Med Microbiol Immunol 1987; 176: 21-26.

5. Kaplan G, Totsuka A, Thompson P, Akatsuka T, Moritsugu Y, Feinstone SM. Identification of surface glycoprotein on African green monkey kidney cells as a receptor for hepatitis A virus. EMBO J 1996; 15: 4282-4296.

6. Ashida M, Hamada C. Molecular cloning of the hepatitis A virus receptor from a simian cell line. J Gen Virol 1997; 78: $1565-1569$.

7. Zajac AJ, Amphlett EM, Rowlands DJ, Sangar DV. Parameters influencing the attachment of hepatitis A virus to a variety of continuous cell lines. J Gen Virol 1991; 72; 1667-1675.

8. Bishop NE, Anderson DA. Early interactions of hepatitis A virus with cultured cells: viral elution and the effect of $\mathrm{pH}$ and calcium ions. Arch Virol 1997; 142: 2161-2178.

9. Madshus IH, Olsnes S, Sandvig K. Requirements for entry of poliovirus RNA into cells at low pH. EMBO $J$ 1984; 3: $1945-1950$.

10. Lonberg-Holm K, Gosser LB, Shimshick EJ. Interaction of liposomes with subviral particles of poliovirus type 2 and rhinovirus type 2. J Virol 1976; 19: 746-749.

11. Fricks CE, Hogle JM. Cell-induced conformational change in poliovirus: externalization of the amino terminus of VP1 is responsible for liposome binding. J Virol 1990; 64: 1934-1945.

12. Fenwick ML, Hall MJ. Factors determining the site of synthesis of poliovirus proteins: the early attachment of virus particles to endoplasmic membranes. J Cell Sci 1973; 3: 403-413.

13. Lonberg-Holm K, Gosser LB, Kauer JC. Early alteration of poliovirus in infected cells and its specific inhibition. $J$ Gen Virol 1975; 27: 329-342.

14. De Sena J, Mandel B. Studies on the in vitro uncoating of poliovirus. I. Characterization of the modifying factor and modifying reaction. Virology 1976; 70: 470-483.

15. Everaert L, Vrijsen R, Boeyé A. Eclipse products of poliovirus after cold-synchronized infection of HeLa cells. Virology 1989; 171: $76-82$.

16. Superti F, Seganti L, Orsi N, Divizia M, Gabrieli R, Panà A. Effect of lipophilic amines on the growth of hepatitis A virus in Frp/3 cells. Arch Virol 1987; 96: 289-296.

17. Superti $\mathrm{F}$, Seganti L, Orsi N, Divizia $M$, Gabrieli R, Panà $\mathrm{A}$ Effect of cellular function inhibitors on the infection of $\operatorname{Frp} / 3$ cells by hepatitis A virus. Med Microbiol Immunol 1987; 178: 29-36.

18. Anderson DA, Ross BC. Morphogenesis of hepatitis A virus: isolation and characterization of subviral particles. $J$ Virol 1990; 64: 5284-5289.

19. Ohkuma S, Poole B. Fluorescence probe measurement of the intralysosomal $\mathrm{pH}$ in living cells and the perturbation of $\mathrm{pH}$ by various agents. Proc Natl Acad Sci USA 1978; 75: 3327-3331.

20. Bishop NE. An update on non-clathrin-coated endocytosis. Rev Med Virol 1997; 7: 199-209.

21. Siegl G, Weitz M, Kronauer G. Stability of hepatitis A virus. Intervirology 1984: 22: 218-226.

22. Scholz E, Heinricy U, Flehmig B. Acid stability of hepatitis A virus. J Gen Virol 1989; 70: $2481-2485$.

23. Anderson DA. Cytopathology, plaque assay, and heat inactivation of hepatitis A virus strain HM175. J Med Virol 1987; 22: 35-44.

24. Anderson DA, Locarnini SA, Ross BC, Coulepis AG, Anderson BN, Gust ID. Single-cycle growth kinetics of hepatitis A virus in BS-C-1 cells. In: Brinton MA, Rueckert RR (eds) Positive strand RNA viruses. New York, Alan R Liss. 1987: 497-507.

25. Bishop NE, Hugo DH, Borovec SV, Anderson DA. Rapid and efficient purification of hepatitis A virus from cell culture. $J$ Virol Methods 1994; 47: 203-216.

26. Borovec SV, Anderson DA. Synthesis and assembly of hepatitis A virus-specific proteins in BS-C-1 cells. $J$ Virol 1993; 67: 3095-3102.

27. Bishop NE, Anderson DA. Hepatitis A virus subviral particles: purification, accumulation, and relative infectivity of virions, provirions and procapsids. Arch Virol 1997; 142: 2147-2160.

28. Skern T, Torgersen H, Auer H, Kuechler E, Blaas D. Human rhinovirus mutants resistant to low $\mathrm{pH}$. Virology 1991; 183: 757-763.

29. Helenius A, McCaslin DR, Fries E, Tanford C. Properties of detergents. Methods Enzymol 1979; 56: 734-749.

30. Bordier C. Phase separation of integral membrane proteins in Triton X-114 solution. J Biol Chem 1981; 256: 1604-1607.

31. Tycko B, Maxfield FR. Rapid acidification of endocytic vesicles containing $\alpha_{2}$-macroglobulin. Cell 1982; 28: 643-651.

32. Geisnow MJ, Evans WH. pH in the endosome: measurements during pinocytosis and receptor-mediated endocytosis. Exp Cell Res 1984; 150: 36-46.

33. Ruchti F, Siegl G, Weitz M. Identification and characterization of incomplete hepatitis A virus particles. J Gen Virol 1991; 72: $2159-2166$.

34. Rueckert RR. Picornaviridae and their replication. In: Fields BN, Knipe DM, Chanock RM et al. (eds) Virology. New York, Raven Press. 1990: 507-548.

35. Bishop NE, Anderson DA. RNA-dependent cleavage of VP0 capsid protein in provirions of hepatitis A virus. Virology 1993; 197: 616-623.

36. Lemon SM, Jansen RW, Newbold JE. Infectious hepatitis A virus particles produced in cell culture consist of three distinct types with different buoyant densities in $\mathrm{CsCl}$. J Virol 1985; 54: $78-85$. 
37. Gauss-Müller V, Lottspeich F, Deinhardt F. Characterization of hepatitis A virus structural proteins. Virology 1986; 155: $732-736$.

38. Locarnini SA, Ferris AA, Stott AC, Gust ID. The relationship between a 22-nm virus-like particle and hepatitis $A$ as demonstrated by immune electron microscopy. Intervirology 1974; 4: 110-118.

39. Bradley DW, Hornbeck CL, Gravelle CR, Cook EG, Maynard JE. $\mathrm{CsCl}$ banding of hepatitis A-associated virus-like particles. $J$ Infect Dis 1975; 131: 304-306.

40. Siegl G, Frösner GG. Characterization and classification of virus particles associated with hepatitis A. I. Size, density, and sedimentation. $J$ Virol 1978; 26: 40-47.

41. Gromeier M, Wetz K. Kinetics of poliovirus uncoating in HeLa cells in a nonacidic environment. $J$ Virol 1990; 64: 3590-3597.

42. Pérez L, Carrasco L. Entry of poliovirus into cells does not require a low-pH step. $J$ Virol 1993; 67: 4543-4548.

43. Wetz $\mathrm{K}$, Kucinski $\mathrm{T}$. Influence of different ionic and $\mathrm{pH}$ environments on structural alterations of poliovirus and their possible relation to virus uncoating. $J$ Gen Virol 1991; 72: 2541-2544. 